\title{
Turkish Publications in Science Citation Index and Citation Index Expanded Indexed Journals in the Field of Toxicology: A Bibliographic Analysis
}

\author{
Sibel Büyükçoban', (olkan Hancı ${ }^{2}$, (i) Leyla İyilikçi ${ }^{1}$ \\ ${ }^{1}$ Department of Anaesthesiology and Reanimation, Dokuz Eylul University Faculty of Medicine, Izmir, Turkey \\ ${ }^{2}$ Department of Anaesthesiology and Reanimation, Division of Intensive Care, Dokuz Eylul University Faculty of Medicine, Izmir, Turkey
}

\begin{abstract}
Introduction: Our study aimed to assess Turkish publications in Science Citation Index (SCI) and Science Citation Index Expanded (SCIE) indexed journals in the field of "toxicology".

Methods: We searched the journals related to "toxicology" in the SCIE database of "Thomson Reuter Web of Science". The search engine of Institute for Scientific Information (ISI) Web of Science (WoS) was used in the advanced mode by typing "IS=ISSN number" to identify publications in the journal. We found Turkish papers on toxicology by typing "IS=ISSN number AND CU=Turkey". If Turkish and non-Turkish authors had collaborated, the article was included in the search when the corresponding author had provided a Turkey-based address. The catalogue information and statistics were used to determine Turkish publications as the percentage of total publications and the annual mean number of Turkish publications. In WoS, "SU=toxicology" was used to determine the number, country, year, and topic distributions of publications from 1975 to date and within the last 10 years. The citation numbers and h-indices were determined based on the country for publications within the last 10 years.

Results: In the area of toxicology, there were 92 journals in the SCI/SCIE index. From 1975 to the early 2000s, Turkey was 19th in the list of countries with highest number of publications on toxicology; however, in the last 10 years, Turkey moved up to $14^{\text {th }}$ place. Its mean citation number has been 7.17, and it remains the lowest country pertaining to citations among the 24 countries with the most number of publications.

Discussion and Conclusion: Our work will also shed light on scientists who are constantly working in the field of toxicology, as well as scientists witnessing unusual toxicological events and wanting to make the academic world knowledgeable.

Keywords: Science citation index; science citation index expanded; Turkey; toxicology.
\end{abstract}

$\mathrm{T}$ he number and quality of scientific publications is an important indicator of a country's scientific activity ${ }^{[1]}$. Information must be overlapped for the rapid advancement of science; and when this synergistic effect is achieved. the desire for scientific research and development will in- crease. Three criteria that highlight international broadcasting activities are generally accepted in the evaluation of academic performance: the number of publications in international scientific journals. the publications in scientific journals scanned by science indices, and the number

Correspondence (İletişim): Volkan Hancı, M.D. Dokuz Eylul Universitesi Anesteziyoloji ve Reanimasyon Anabilim Dali, Yogun Bakim Bilim Dali, Izmir, Turkey

Phone (Telefon): +90 5306433240 E-mail (E-posta): volkan.hanci@deu.edu.tr

Submitted Date (Başvuru Tarihi): 21.02.2018 Accepted Date (Kabul Tarihi): 02.04.2018

Copyright 2019 Haydarpaşa Numune Medical Journal

OPEN ACCESS This is an open access article under the CC BY-NC license (http://creativecommons.org/licenses/by-nc/4.0/) 
of references to publications ${ }^{[1]}$. In recent years, there has been an increase in bibliographic publications in the literature ${ }^{[3]}$. In the light of these bibliographic studies, the number of articles sent from clinics of anesthesia in Turkey and published in valuable high-impact international journals have tended to decrease within the last 10 years. The average number of citations is below the world average ${ }^{[2]}$.

In a report prepared in 2009 by the scientists under the supervision of Higher Education Council (YÖK) where scientific indicators of Turkey were analyzed, the relative citation impact of Turkey is determined to be below the world average in all areas ${ }^{[4]}$. In our literature review, it has been indicated that bibliographic analyses of publications from our country have been performed in many branches, while studies analyzing publications on one of the most comprehensive disciplines namely toxicology sent from Turkey have not been conducted yet.

This study aimed to quantitatively and qualitatively assess articles coming from Turkey and published in toxicology journals included in the lists of Science Citation Index (SCI) and $\mathrm{SCI}$ Expanded (SCIE) and compare the relevant data with the international data.

\section{Materials and Methods}

Our study was designed as a retrospective observational study. The study was started after obtaining the approval from Dokuz Eylül University Ethics Committee on Noninvasive Investigations (decision no. 2017/20-05). The term toxicology was selected from the Thomson Reuters Web of Science database and in journals included in SCIE. The list of journals in the SCIE index and their ISSN numbers were obtained. The IS=ISSN number was printed in the advanced mode of the search engine of Web of Science (WoS) of Scientific Information (ISI) all issues of the journal were determined. The "IS=ISSN number of AND CU= Turkey" were recorded, and all articles on toxicology sent from Turkey were determined (on 30.15.2017).

We applied the same procedure in the PubMed database, and performed double check. Articles prepared by Turkish and non-Turkish authors in collaboration were included in the study if the responsible author of the article was residing in Turkey. Catalog information, duration of publication, number of issues, the number of publications from Turkey, proportion (\%) of all articles from Turkey in all issues of the relevant journal using impact factors, and average annual rate of Turkey-based publications were determined.

\section{Acceptance Rate (\%) of Turkey-based Publications}

The number of Turkey-based publications in a journal mul- tiplied by 100 and divided by the total number of publications of the same journal indicates acceptance rate of Turkey-based publications.

\section{Average Rate of Annual Publications from Turkey}

The number of Turkey-based publications in a journal divided by the duration of its publication counted from the first year of its release as specified in the catalog information of the journal yields annual mean number of publications. It demonstrates the number of Turkey-based articles published in this journal. It is defined as the annual mean publication rate of Turkey-based articles in this journal.

In the second phase of the study, the word "SU=toxicology" was entered in the advanced mode, in the WoS search engine of ISI, and all publications indexed in the field of toxicology were accessed.

By typing "Analyze Results", the distribution of all publications according to countries, years, fields of publication, and topics was determined and listed. We determined the distribution of topics by taking into account all topics of articles published from 1975 on, and also within the last decade. Then, the words "SU=toxicology AND CU=country name" was entered in the advanced mode of the WoS search engine of ISI, and typing "Citation Report" all h-index values of all countries were determined. In addition, by typing "SU=toxicology AND CU=Turkey" "Analyze Results" only the publications of our country were determined and listed according to years and subjects.

The primary endpoint of this study was to determine acceptance rate of Turkey-based publications by journals in the field of toxicology included in the $\mathrm{SCI} / \mathrm{SCIE}$ index and the annual mean publication rate, while the secondary endpoint was to compare the number of citations received by Turkey-based publications, and their h-indices with those of the other countries.

\section{Statistical Analysis}

The data of the study were analyzed with the Statistical Package for the Social Sciences15.0 (SPSS Inc; Chicago, IL, USA) package program For statistical evaluation of the publication rates ${ }^{[5]}$ of the journals grouped by different criteria and Turkey-based publications and their annual mean publication rates, the Mann-Whitney $U$ test was used. The correlations between impact factors of the journals, publication rates of Turkey-based journals, and their average annual publication rates were analyzed by Pearson correlation test. $p$ value less than 0.05 was considered statistically significant. 


\section{Results}

A total of 92 journals in the field of toxicology were included in the SCI/SCIE index (Appendix 1). The journals with the highest publication rate from our country were determined as Cutaneous and Ocular Toxicology, Toxicology and Industrial Health, Human \& Experimental Toxicology, Food Additives \& Contaminants: Part B-Surveillance, and Journal of Food Safety and Food Quality-Archiv für Lebensmittelhygiene (Appendix 2).

We did not encounter any Turkey-based publication in 10 journals listed in the SCI/SCIE index (Annals of Occupational Hygiene; BMC Pharmacology and Toxicology; Critical Reviews in Toxicology; Integrated Environmental Assessment and Management; Journal of Environmental Science and Health, Part C: Environmental Carcinogenesis and Ecotoxicology Reviews; Journal of Exposure Science and Environmental Epidemiology; Journal of Toxicologic Pathology; Journal of Toxicology and Environmental Health, Part B: Critical Reviews; Molecular \& Cellular Toxicology; Particle and Fibre Toxicology).

In 23 journals (25\%), the number of publications from our country was determined as five and less than five. Evaluation of journals of toxicology indexed in SCI/SCIE according to their catogeries, number of publication fields of toxicology in Turkey and world between 1975-2016 and 20072016 were shown in Table 1, 2, 3, respectively.

Annual distrubition of publications in the field of toxicology within the last 10 years both in Turkey and in the World are shown in table 4. Distrubition of types of publications in the years between 1975-2016 and 2007-2016 both in Turkey and in the World are shown in table 5.

In our study, any significant correlation could not be determined between inclusion of the journals in $\mathrm{SCl}$ or SCIE index, and publication rates of Turkey-based publications, and their average number of annual publications ( $p>0.05$ ). In addition, a significant correlation did not exist between the geographic location (continent) of the place of publication of the journal, and publication rates, and annual mean number of publications coming from Turkey ( $p>0.05)$.

In our study, a negative correlation was determined between the increase of impact factors of the journals and the percentage of publications accepted from our country $(p=0.038 ; r=-0.217)$. The increase in the impact factor of the journals resulted in a significant decrease in the number of publications from our country. Although there was a negative correlation between the impact factor of the journals and the number of annual publications pertaining to our country, no significant correlation could be determined $(p=0.107 ; r=-0.167)$. In our study, both worldwide and in the last decade, the first three subareas in the field of toxicology have been identified as environmental sciences, ecology, and pharmacology and public health occupational diseases. In our country, these fields have been listed as pharmacology, environmental sciences, ecology, and public health occupational diseases since 1975 and within the last decade (Table 2).

The number of publications in the field of toxicology in our country has increased within the next 10 years, remarkably in 2015 and 2016. In addition, the average number of citations of the publications in our country in the field of toxicology and the h-index of our country were found to be lower compared to the countries with the same publication rates.

\section{Discussion}

In our study, we determined that the papers from our country in the field of toxicology were published in the following journals entitled Cutaneous and Ocular Toxicology, Toxicology and Industrial Health, Human \& Experimental Toxicology, Food Additives \& Contaminants, Part B-Surveillance, and Journal of Food Safety and Food Quality-Archiv für Lebensmittelhygiene.

It has been indicated that only five or less than five papers were published in 23 (25\%) different journals released in the field of toxicology, and a negative correlation was found between increase in the impact factors of the journals and the percentage of publications accepted from Turkey. Among the countries with the highest number of publications in the field of toxicology, Turkey ranked 19th in 1975 , and moved up to $14^{\text {th }}$ place within the last 10 years. With its average number of citations ${ }^{[7,17]}$, it has the lowest number of citations among 24 countries with the greatest number of publications.

The studies that evaluate the scientific productivity of individuals, institutions, and countries in various fields are gradually increasing in the literature of our country and worldwide. The evaluation of scientific productivity of individuals, institutions, and countries can be measured using various objective parameters. The use of measurements such as number of publications, number of citations, and hindex in monitoring the performance of scientists contributes to the advancement of science as well as comparing the researchers to each other. Impact factor is an important criterion to demonstrate the effectiveness of the studies. Scientific studies that analyze such parameters are classi- 
fied as bibliometric studies ${ }^{[5]}$.

Bibliometric studies have been carried out in various scientific fields worlwide and in our country. For example, a bibliometric study was conducted in the international literature in the field of anesthesiology. Boldt et al. ${ }^{[6]}$ examined the articles related to anesthesia, intensive care, and pain published in the SCl journals between 1997 and 1998. They stated that America has the highest number of publications. Bould et al. analyzed the studies in the field of anesthesia and indicated that the articles from highincome countries were more frequently published, while only scarce number of articles from low-income countries such as Turkey, China, and India found the possibility of publication ${ }^{[7]}$.

In a bibliometric study, Yilmaz et al. ${ }^{[8]}$ evaluated scientific performance of the publications in the field of anesthesiology both worldwide and in Turkey. According to the results of the study from 2004 to 2009, a serious decline in the number of total Turkey-based publications in anesthesiology journals was determined. However, publication rate increased again after 2009. They reported that Turkish authors more frequently preferred the journal of Pediatric Anesthesia relative to other journals. In this study, the top five countries with the highest number of publications in the field of anesthesiology were developed countries as United States, England, Germany, France, and Canada. In this study, Turkey ranked $14^{\text {th }}$ among them. In the light of all the findings they obtained, the authors concluded that continuous and consistent scientific publication policies supported by the state should be established to place Turkey in a certain scientific position worldwide ${ }^{[8]}$.

Among the bibliographic studies published in the field of toxicology, the studies of Zyoud et al. ${ }^{[9]}$ are remarkable. Zyoud et al. ${ }^{[9]}$ examined publications on cocaine performed between 1975 and 2015. They emphasized that the studies in this area have increased after 1990 and that the United States and Spain had conducted the highest number of studies on the subject.

Zyoud also bibliometrically investigated the place of studies in the literature regarding methanol intoxications ${ }^{[10]}$, calcium channel blocker intoxications [11], use of intravenous lipid emulsions ${ }^{[12]}$, and treatment schemes as $\mathrm{N}$ acetyl cysteine use in paracetamol intoxications ${ }^{[13]}$ in the field of toxicology.

In our literature review, no bibliographic study was found in the field of toxicology performed in Turkey. The fact that toxicology is a multidisciplinary field is forcing the scientists who are performing toxicology studies with the intention to prepare and publish their works. In spite of its increasing importance in our country and worldwide, toxicology is not taking its expected place in the medical literature.

In our review we conducted in the field of toxicology, the relationship between the various features of the journals and the rates of Turkey-based publications was examined in addition to the journals with the highest rates of publications from our country.

Significant correlations could not be found between the language of the journal, the continent of the country where the article was published, the inclusion of the journal in the $\mathrm{SCl}, \mathrm{SCIE}$ index, the publication rate of Turkey-based publications, and the annual mean number of publications from our country.

In our study, the countries with the highest number of publications in the field of toxicology have been examined from the year 1975 up to now; and within the last 10 years, while and among the top five countries, the United States, Japan, United Kingdom, Germany, and China have been observed. Turkey ranks $19^{\text {th }}$ in the period from 1975 up to now.

Australia, Denmark, Scotland, Norway, and Spain (between 19.26 and 14.31) were among the top five countries with the highest average citation rate. The countries with the highest number of publications are not the same with the most citations. The same is true for the citation rates of the countries with the highest number of publications. The average citation rate of Turkey was 7.17.

The proportion of publications in the field of toxicology originating from our country to toxicology publications worldwide increased from $0.55 \%$ between the years 1975 and 2006 up to $2.14 \%$ in the last 10 years. Considering the distribution of Turkey-based publications within the last 10 years, the lowest publication rate was $5.06 \%$ in the year 2009 , and publication rates fluctuated until 2014. However, an increasing trend was observed from the year 2014 on, and the highest publication rate within the last 10 years was reached with $12.86 \%$ in 2016 .

In our analysis, especially in recent years, the increase in the number of publications in our country in the field of toxicology among total number of relevant publications worldwide is remarkable. However, Turkey is the country with the lowest citation average within the last 10 years, which indicates that the publications do not reach sufficient quality. The results of our study support the work of Onat ${ }^{[14]}$ and Özbilgin ${ }^{[15]}$ in this respect, and a deep and multifaceted effort is needed to shape an environment that focuses on research that can contribute to medicine in the field of toxicology. In the last 10 years, the growth rates of 
China, Spain, South Korea, and Brazil have increased, and consequently a striking increase in the number of publications is observed. This result was similar to that of Yilmaz et al. ${ }^{[8]}$ and Özbilgin et al. ${ }^{[14]}$.

When the publications in the field of toxicology were analyzed from 1975 up to now, publications on pharmacology, environmental science and ecology, public health, occupational diseases, genetics, and hereditary diseases are more numerous all over the world, while in Turkey most frequently publications were made in the fields of environmental science and ecology, pharmacology, public health, occupational diseases, food science and technology, chemistry, ophthalmology, and genetics. Number of publications on genetics rank fourth worldwide, while it falls to seventh place in our country. This finding may be attributed to the higher costs of investment in genetic studies.

Although ophthalmology studies worldwide are not widely published in toxicology journals, ophthalmology occupies an important place in toxicological studies in our country. This situation can be attributed to the lack of protection of the eye from toxic substances in our country.

In our study, both Thomson Reuters Web of Science and PubMed-databases were included in the data analysis. Besides Turkey-based publication rates in the SCI/SCIE indexed journals, the factors affecting them were also investigated. Some scientific journals also publish poster presentations of the congresses they are associated with in the Thomson Reuters Web of Science database.

The data obtained in this case may be scientifically controversial as they will include poster presentations. In this study, we evaluated both databases and we did not include poster presentations in statistical analysis, and only used data from PubMed database to make more accurate data analysis. In our study, instead of these data, we scanned SCI/SCIE indexed journals in the field of toxicology that would provide us more objective data about publication rates and average annual publication rates of Turkey-based publications.

In our study, we determined that the following journals accepted the highest number of manuscripts from our country for publication:

Cutaneous and Ocular Toxicology, Toxicology and Industrial Health, Human \& Experimental Toxicology, Food Additives \& Contaminants: Part B-Surveillance, Journal of Food Safety and Food Quality-Archiv für Lebensmittelhygiene. We did not encounter any Turkey-based publication in 10 journals listed in the SCI/SCIE index (Annals of Occupational Hygiene, BMC Pharmacology and Toxicology, Critical Reviews in Toxicology, Integrated Environmental Assessment and Management, Journal of Environmental Science and Health: Part CEnvironmental Carcinogenesis and Ecotoxicology Reviews, Journal of Exposure Science and Environmental Epidemiology, Journal of Toxicologic Pathology, Journal of Toxicology and Environmental Health: Part B-Critical Reviews, Molecular \& Cellular Toxicology, Particle and Fibre Toxicology).

In 23 of the journals (25\%), the number of publications from our country was determined as five and less than five. In our study, no significant relationship could be determined between inclusion of journals in the $\mathrm{SCl}$ or SCIE indices, publication rates (\%) and mean number of annual publications in Turkey $(p>0.05)$. In addition, a significant relationship did not exist between the geographic location of the publication place (continent) of the journal and both publication rates $(\%)$, and mean number of annual publications in Turkey $(p>0.05)$.

In our study, we determined the presence of a negative correlation between the increase in impact factors of the journals and the acceptance rate of Turkey-based publications $(p=0.038 ; r=-0.217)$. The increase in the impact factor of the journals resulted in a significant decrease in the number of publications from our country. A negative but nonsignifi-

Table 1. Evaluation of the journals of toxicology indexed in $\mathrm{SCl} / \mathrm{SCl}-\mathrm{E}$ according to their categories

\begin{tabular}{|c|c|c|c|c|c|}
\hline & Category & $\begin{array}{c}\text { Annual number of } \\
\text { publications } \\
\text { (mean } \pm \text { SD) }\end{array}$ & $\begin{array}{l}\text { Annual number of } \\
\text { publications } \\
\text { in Turkey } \\
\text { (mean } \pm \text { SD) }\end{array}$ & $\begin{array}{l}\text { Publication rate (\%) } \\
\text { of Turkey-based } \\
\text { publications } \\
\text { (mean } \pm \text { SD) }\end{array}$ & $\begin{array}{c}\text { Turkey-based } \\
\text { publication rate } \\
\text { (mean } \pm \text { SD) }\end{array}$ \\
\hline \multirow[t]{2}{*}{$\mathrm{SCl} / \mathrm{SCIE}$} & $\mathrm{SCl}(\mathrm{n}=65)$ & $3374.50 \pm 3042.01$ & $33.75 \pm 55.64$ & $1.38 \pm 2.00$ & $1.21 \pm 1.86$ \\
\hline & SCIE $(n=27)$ & $1096.25 \pm 775.84$ & $32.03 \pm 73.25$ & $2.87 \pm 6.86$ & $1.58 \pm 4.02$ \\
\hline $\mathrm{p}$ & & $<0.001$ & 0.111 & 0.843 & 0.205 \\
\hline \multirow[t]{2}{*}{ Geographic region } & Europe $(n=40)$ & $2848.40 \pm 3374.13$ & $25.42 \pm 54.27$ & $1.82 \pm 5.34$ & $1.19 \pm 3.11$ \\
\hline & Other (52) & $2596.26 \pm 2264.24$ & $39.26 \pm 65.46$ & $1.82 \pm 2.84$ & $1.41 \pm 2.29$ \\
\hline $\mathrm{p}$ & & 0.670 & 0.282 & 0.992 & 0.687 \\
\hline
\end{tabular}


cant correlation existed between the impact factor of the journals and the number of annual publications from our country, $(p=0.107 ; r=-0.167)$.

Although publication rate and average annual publication rates of Turkey-based publications in European journals were lower when compared with non-European journals, the difference was not statistically significant (Table 1).

As a widely accepted opinion among authors, as the "impact factor" of the journals increase the likelihood of acceptance or publication of the manuscript decreases. Our study supports this view. A negative correlation was determined between the increase in the impact factors of toxicology journals and the percentage of publications accepted from our country $(p=0.038, r=-0.217)$. The publication fields in toxicology of Turkey and the world between 1975 and 2017 are shown in Table 2.
As a limitation of our study, in articles written by Turkish and non-Turkish authors in collaboration, the articles were taken into consideration if the responsible author is living in Turkey.

The first condition of taking place among the developed countries in terms of scientific publications is to conduct numerous and high-quality researches. In the last decade, there has been an increase in the number and publication of articles published in the field of toxicology and publication rates in the indexed journals thanks to the scientific contribution of the countries that appreciated the importance of this issue both in the world and in our country (Tables 3, 4).

Bibliographic surveys not only are a good indicator of publication performance of our scientists but also help those with the idea of making publications in the field

Table 2. Number (\%) of publication fields of journals of toxicology between the years 1975 and 2016 both in Turkey and in the World

\begin{tabular}{|c|c|c|c|c|c|c|c|c|}
\hline & \multicolumn{4}{|c|}{ In Turkey } & \multicolumn{4}{|c|}{ In the World } \\
\hline & $\begin{array}{c}\text { Total } \\
\text { number }\end{array}$ & $\%$ & $\begin{array}{c}\text { Total } \\
\text { number }\end{array}$ & $\%$ & $\begin{array}{c}\text { Total } \\
\text { number }\end{array}$ & $\%$ & $\begin{array}{c}\text { Total } \\
\text { number }\end{array}$ & $\%$ \\
\hline Pharmacology & 633 & 14.91 & 421 & 13.38 & 101788 & 28.87 & 41630 & 28.99 \\
\hline $\begin{array}{l}\text { Environmental sciences, } \\
\text { ecology }\end{array}$ & 797 & 18.77 & 519 & 16.81 & 78800 & 22.35 & 30122 & 20.97 \\
\hline $\begin{array}{l}\text { Public health, occupational } \\
\text { diseases }\end{array}$ & 508 & 11.97 & 413 & 13.38 & 36873 & 10.45 & 13918 & 9.69 \\
\hline Genetics, hereditary diseases & 181 & 4.26 & 76 & 2.46 & 33335 & 9.45 & 9471 & 6.59 \\
\hline Chemistry & 320 & 7.54 & 227 & 7.35 & 21195 & 6.01 & 7943 & 5.53 \\
\hline $\begin{array}{l}\text { Biochemistry, and molecular } \\
\text { biology }\end{array}$ & 132 & 3.13 & 75 & 2.43 & 18284 & 5.186 & 6695 & 4.66 \\
\hline Developmental biology & 17 & 0.40 & 12 & 0.38 & 9853 & 2.79 & 2891 & 2.01 \\
\hline Freshwater biology & 31 & 0.73 & 17 & 0.55 & 8749 & 2.48 & 3797 & 2.64 \\
\hline Neurologic sciences & 27 & 0.63 & 16 & 0.51 & 7616 & 2.16 & 2723 & 1.89 \\
\hline Zoology & 57 & 1.34 & 28 & 0.90 & 6996 & 1.98 & 1696 & 1.18 \\
\hline $\begin{array}{l}\text { Endocrinology, and diseases } \\
\text { of metabolism }\end{array}$ & 40 & 0.94 & 10 & 0.32 & 6121 & 1.73 & 1107 & 0.77 \\
\hline Pathology & 83 & 1.95 & 60 & 1.94 & 6037 & 1.71 & 2558 & 1.78 \\
\hline Medical laboratory technology & 16 & 0.37 & 12 & 0.38 & 5532 & 1.56 & 2273 & 1.58 \\
\hline Veterinary sciences & 52 & 1.22 & - & - & 4632 & 1.31 & - & - \\
\hline Substance dependence & 7 & 0.16 & 6 & 0.19 & 3467 & 0.98 & 1260 & 0.87 \\
\hline Forensic medicine & 10 & 0.23 & 7 & 0.22 & 3322 & 0.94 & 1783 & 1.24 \\
\hline
\end{tabular}


Table 3. Number of publications in Turkey and in the World between the years 1975-2016 and 2007-2016

\begin{tabular}{|c|c|c|c|c|c|c|c|c|}
\hline \multirow[t]{2}{*}{ Country } & \multicolumn{2}{|c|}{ 1975-2016 } & \multicolumn{2}{|c|}{ 1975-2006 } & \multicolumn{4}{|c|}{ 2007-2016 } \\
\hline & $\begin{array}{c}\text { Total } \\
\text { number of } \\
\text { publications }\end{array}$ & $\begin{array}{c}\text { Publication } \\
\text { rates (\%) }\end{array}$ & $\begin{array}{c}\text { Total } \\
\text { number of } \\
\text { publications }\end{array}$ & $\begin{array}{c}\text { Publication } \\
\text { rates (\%) }\end{array}$ & $\begin{array}{c}\text { Total } \\
\text { number of } \\
\text { publications }\end{array}$ & $\begin{array}{l}\text { Publication } \\
\text { rates (\%) }\end{array}$ & $\begin{array}{l}\text { Average number } \\
\text { of citations }\end{array}$ & $h$ - indices \\
\hline USA & 126325 & 35.83 & 83528 & 39.97 & 42797 & 29.98 & & \\
\hline Japan & 23080 & 6.54 & 15444 & 7.39 & 7637 & 5.31 & 9.41 & 75 \\
\hline Germany & 17038 & 4.83 & 8790 & 4.20 & 8248 & 5.74 & 12.4 & 101 \\
\hline China & 16333 & 4.63 & 2653 & 1.27 & 13680 & 9.67 & & \\
\hline Canada & 15871 & 4.50 & 9659 & 4.62 & 6211 & 4.32 & 13.39 & 97 \\
\hline French & 13800 & 3.91 & 7576 & 3.62 & 6224 & 4.33 & 12.00 & 87 \\
\hline Italy & 13059 & 3.70 & 6820 & 3.26 & 6239 & 4.34 & 12.71 & 91 \\
\hline Sweden & 8713 & 2.47 & 5763 & 2.75 & 2694 & 1.87 & 9.04 & 59 \\
\hline Brazil & 7362 & 2.08 & 2450 & 1.17 & 4912 & 3.42 & 13.70 & 75 \\
\hline South Korea & 6610 & 1.87 & 1697 & 0.81 & 4913 & 3.42 & 13.01 & 90 \\
\hline Australia & 5882 & 1.66 & 3311 & 1.58 & 2571 & 1.79 & 19.26 & 117 \\
\hline Switzerland & 5401 & 1.53 & 2707 & 1.29 & 2694 & 1.87 & 13.70 & 75 \\
\hline Belgium & 4965 & 1.40 & 2553 & 1.22 & 2412 & 1.68 & 13.08 & 70 \\
\hline Denmark & 4478 & 1.27 & 2521 & 1.20 & 1957 & 1.36 & 17.32 & 75 \\
\hline Turkey & 4244 & 1.20 & 1158 & 0.55 & 3086 & 2.14 & 7.17 & 52 \\
\hline Taiwan & 4056 & 1.15 & 1775 & 0.84 & 2281 & 1.58 & 12.03 & 55 \\
\hline
\end{tabular}

Table 4. Annual distribution of publications in the field of toxicology within the last 10 years both in Turkey and in the World

\begin{tabular}{cccccc}
\hline & \multicolumn{2}{c}{ In Turkey } & & \multicolumn{2}{c}{ In the World } \\
\cline { 2 - 3 } & $\begin{array}{c}\text { Total } \\
\text { number }\end{array}$ & $\%$ & & $\begin{array}{c}\text { Total } \\
\text { number }\end{array}$ & $\%$ \\
\hline 2007 & 227 & 5.34 & & 11736 & 3.32 \\
2008 & 239 & 5.63 & & 13355 & 3.78 \\
2009 & 215 & 5.06 & & 14029 & 3.97 \\
2010 & 240 & 5.65 & & 13671 & 3.87 \\
2011 & 323 & 7.61 & & 14656 & 4.15 \\
2012 & 298 & 7.02 & & 14500 & 4.13 \\
2013 & 361 & 8.50 & & 14633 & 4.15 \\
2014 & 300 & 7.06 & & 15414 & 4.37 \\
2015 & 337 & 8.50 & & 14952 & 4.24 \\
2016 & 546 & 12.86 & & 16644 & 4.72 \\
& 4244 & 100 & & 352552 & 100 \\
\hline
\end{tabular}

of toxicology. Toxicology continues to be a common area of many disciplines both worldwide and in our country. It is also very difficult to make publications in this multidisciplinary field. Toxicology is a branch of science that attracts interests of experts in many different fields such as forensic experts, pharmacists, anesthetists, chemists, and others. Specialists working in fields of forensic toxicology, emergency toxicology, and analytical toxicology are not aware of each other. In this context, the selection of a journal for submission of manuscripts that are likely to be published in journals of many disciplines has a great importance.

As a result, our study will shed light on the scientists who are constantly working in the field of toxicology and witness the extraordinary toxicological events as well as the scientists in the academic world who want to make sci- 
Table 5. Distribution of types of publications in the years between 1975-2016 and 2007-2016 both in Turkey and in the World

\begin{tabular}{|c|c|c|c|c|c|c|c|c|}
\hline & \multicolumn{3}{|c|}{ In Turkey } & & \multicolumn{4}{|c|}{ In the World } \\
\hline & $\begin{array}{c}\text { Total } \\
\text { number }\end{array}$ & $\%$ & $\begin{array}{c}\text { Total } \\
\text { number }\end{array}$ & $\%$ & $\begin{array}{c}\text { Total } \\
\text { number }\end{array}$ & $\%$ & $\begin{array}{c}\text { Total } \\
\text { number }\end{array}$ & $\%$ \\
\hline Articles & 3266 & 76.95 & 2268 & 73.49 & 243286 & 69.0 & 92812 & 64.6 \\
\hline Case presentations & 817 & 19.25 & 709 & 22.97 & 56843 & 16.1 & 33755 & 23.5 \\
\hline Review articles & 50 & 1.17 & 44 & 1.42 & 18829 & 5.3 & 9218 & 6.42 \\
\hline Letter to the editor & 12 & 0.28 & 11 & 0.35 & 9283 & 2.6 & 3189 & 2.22 \\
\hline Letters & 55 & 1.29 & 39 & 1.26 & 5265 & 1.4 & 2097 & 1.46 \\
\hline Notes & 8 & 0.18 & - & - & 2872 & 0.8 & - & - \\
\hline Total & 4244 & 100 & 3086 & 100 & 352552 & 100 & 143590 & 100 \\
\hline
\end{tabular}

entific contributions to the field of toxicology. From time to time, such publications should be reevaluated and updated to maintain their current status and should be revised based on literature reviews.

Ethics Committee Approval: The study was started after obtaining the approval from Dokuz Eylül University Ethics Committee on Noninvasive Investigations (Decision no. 2017/20-05).

Peer-review: Externally peer-reviewed.

Authorship Contributions: Concept: V.H.; Design: S.B., L.I.; Data Collection or Processing: S.B., L.I.; Analysis or Interpretation: V.H.; Literature Search: S.B., V.H.; Writing: S.B.

Conflict of Interest: None declared.

Financial Disclosure: The authors declared that this study received no financial support.

\section{References}

1. Ak MZ, Gülmez A. Türkiye'nin uluslararası yayın performansının analizi. Akademik Incelemeler Dergisi 2006;1:22-49.

2. Yılmaz HO, Babazade R, Turan OA, Babazade B, Koyuncu O, Turan A. Scientific Publication Performance of Turkish Anaesthesia Clinics in High Impact Factor International Journals Between 2005 and 2014: A Bibliometric Analysis. Turk J Anaesthesiol Reanim 2017;45:16-25. [CrossRef]

3. Glanville J, Kendrick T, McNally R, Campbell J, Hobbs FD. Research output on primary care in Australia, Canada, Germany, the Netherlands, the United Kingdom, and the United States: bibliometric analysis. BMJ 2011;342:d1028. [CrossRef]

4. Karasozen B, Bayram G, Zan BU. 1997-2006 Türkiye Bilim Göstergeleri Analizi. Türk Kütüphaneciliği 2009;23:4-21.

5. Hirsch JE. An index to quantify an individual's scientific research output. Proc Natl Acad Sci U S A 2005;102:16569-72.

6. Boldt J, Maleck W, Koetter KP. Which countries publish in im- portant anesthesia and critical care journals? Anesth Analg 1999;88:1175-80. [CrossRef]

7. Bould MD, Boet S, Riem N, Kasanda C, Sossou A, Bruppacher HR. National representation in the anaesthesia literature: a bibliometric analysisof highly cited anaesthesia journals. Anaesthesia 2010;65:799-804. [CrossRef]

8. Yılmaz S, Bakış M. A Bibliometric Analysis of Scientific Publications from Turkey and the World in the Field of Anesthesiology. Türkiye Klinikleri J Anesth Reanim 2014;12:143-7.

9. Zyoud SH, Waring WS, Al-Jabi SW, Sweileh WM. Global cocaine intoxication research trends during 1975-2015: a bibliometric analysis of Web of Science publications. Substance Abuse Treatment, Prevention, and Policy 2017;12:6. [CrossRef]

10. Zyoud SH, Al-Jabi SW, Sweileh WM, Awang R, Waring WS. Bibliometric profile of the global scientific research on methanol poisoning (1902-2012). J Occup Med Toxicol 2015;10:17. [CrossRef]

11. Zyoud SH, Al-Jabi SW, Sweileh WM, Waring WS. Scientific research related to calcium channel blockers poisoning: $\mathrm{Bi}-$ bliometric analysis in Scopus, 1968-2012. Hum Exp Toxicol 2015;34:1162-70. [CrossRef]

12. Zyoud SH, Waring WS, Al-Jabi SW, Sweileh WM, Rahhal B, Awang R. Intravenous Lipid Emulsion as an Antidote for the Treatment of Acute Poisoning: A Bibliometric Analysis of Human and Animal Studies. Basic Clin Pharmacol Toxicol 2016;119:512-9. [CrossRef]

13. Zyoud SH, Al-Jabi SW, Sweileh WM, Awang R, Waring WS. Global research productivity of $\mathrm{N}$-acetylcysteine use in paracetamol overdose: A bibliometric analysis (1976-2012). Hum Exp Toxicol 2015;34:1006-16. [CrossRef]

14. Onat A. Status of Turkey's top publications in cardiovascular medicine, revisited after 4 years. Turk Kardiyol Dern Ars 2016;44:320-8. [CrossRef]

15. Özbilgin Ş, Hancı V. Turkish Publications in Science Citation Index and Citation Index-Expanded Indexed Journals in the Field of Anaesthesiology: A Bibliographic Analysis. Turk J Anaesthesiol Reanim 2017;45:26-35. [CrossRef] 
Appendix 1. Catalogue information of the journals included in the $\mathrm{SCl} / \mathrm{SCIE}$ index

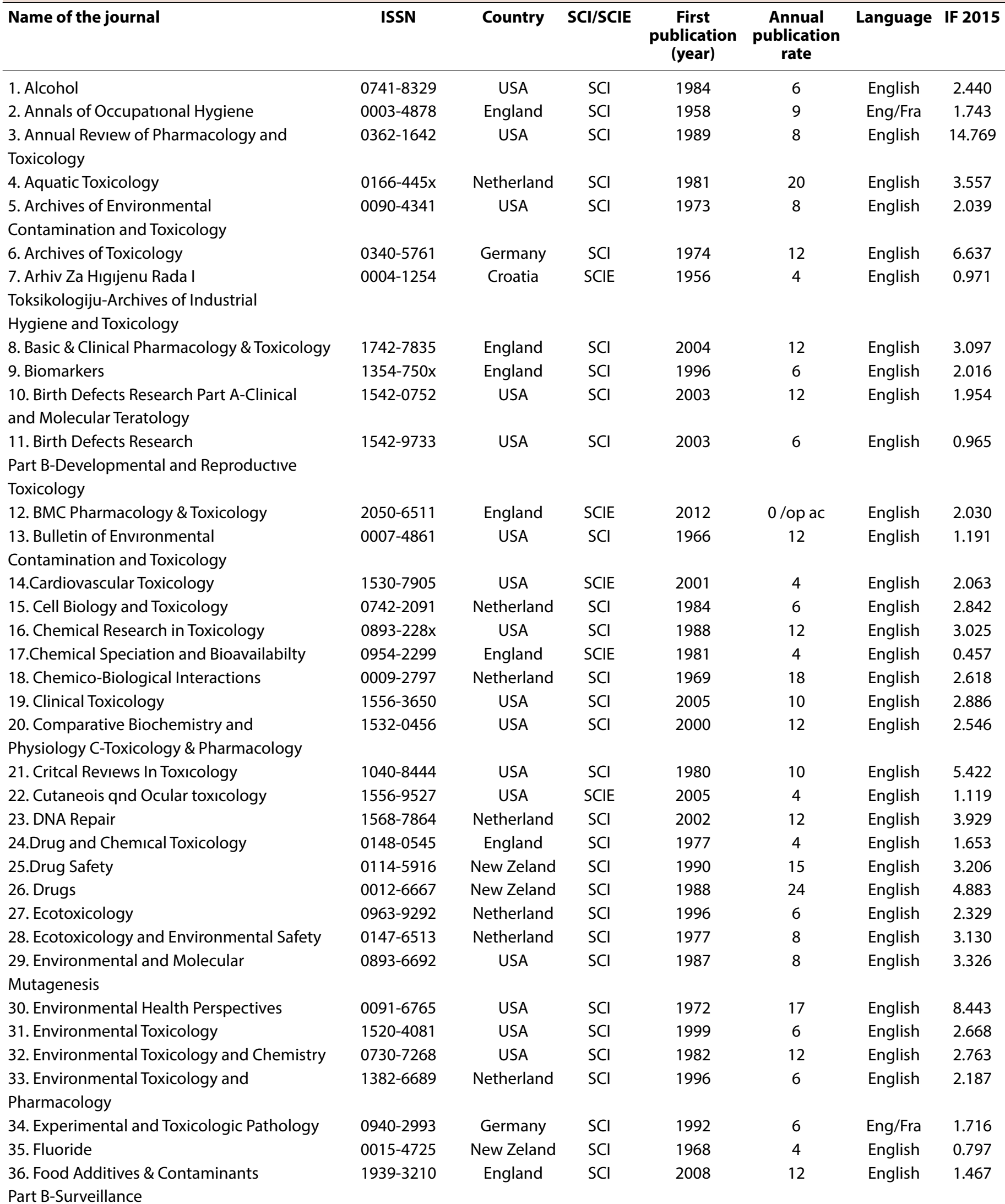


Appendix 1. Cont.

Name of the journa

\section{ISSN \\ Country SCI/SCIE}

First publication (year)
Annual Language IF 2015 ublication rate
37. Food Additives and Contaminants

Part A-Chemistry Analysis Control

Exposure \& Risk Assessment

38. Food and Agricultural Immunology

39. Food and Chemical Toxicology

40. Forensic Toxicology

41. Human \& Experimental Toxicology

42. Immunopharmacology and

Immunotoxicology

43. Industrial Health

44. Inflammopharmacology

45. Inhalation Toxicology

46. Integrated Environmental

Assessment and Management

47. International Journal of Toxicology

48. Journal of Analytical Toxicology

49. Journal of Applied Toxicology

50. Journal of Biochemical and Molecular

Toxicology

51. Journal of Environmental

Pathology Toxicology and Oncology

52. Journal of Environmental Science

and Health Part C-Environmental

Carcinogenesis \& Ecotoxicology Reviews

53. Journal of Exposure Science and

Environmental Epidemiology

54. Journal of Food Safety and Food

Quality-Archiv Fur Lebensmittelhygiene

55. Journal of Immunotoxicology

56. Journal of Pharmacological and

Toxicological Methods

57. Journal of Toxicologic Pathology

58. Journal of Toxicological Sciences

59. Journal of Toxicology and Environmental

Health-Part A-Current Issues

60. Journal of Toxicology and Environmental

Health-Part B-Critical Reviews

61. Journal of Venomous Animals and

Toxins Including Tropical Diseases

62. Marıne Envıronmental Research

63. Molecular \& Cellular Toxicology

64. Mutagenesis

65. Mutation Research-Fundamental and

Molecular Mechanisms of Mutagenesıs

66. Mutation Research-Genetic Toxicology

and Environmental Mutagenesis

67. Mutation Research-Reviews In Mutatıon

Research
1944-0049

England

$\mathrm{SCl}$

2008

12

English

1.878

$0954-0105$
$0278-6915$
$1860-8965$
$0960-3271$
$0892-3973$
$0019-8366$
$0925-4692$
$0895-8378$
$1551-3777$

$\begin{array}{ccc}\text { Germany } & \text { SCIE } & 1992 \\ \text { England } & \text { SCI } & 1982 \\ \text { Japan } & \text { SCIE } & 2006 \\ \text { England } & \text { SCI } & 1990 \\ \text { USA } & \text { SCI } & 1987\end{array}$

1091-5818

0146-4760

0260-437X

$1095-6670$

Japan

SCIE

1963

Switzerland SCIE $\quad 1991$

England $\quad \mathrm{SCl} \quad 1989$

USA

SCIE

2005

USA

England

SCIE

1997

England

$\mathrm{SCl}$

1977

1981

USA

SCIE

1998

0731-8898

USA

SCIE

1985

1059-0501

USA

$\mathrm{SCl}$

1991

1559-0631

USA

$\mathrm{SCl}$

2006

0003-925X

Germany

$\mathrm{SCl}$

$1955^{*}$

1547-691X

1056-8719

England

USA

SCIE

2004

1992

0914-9198

0388-1350

1528-7394

Japan

Japan

England

SCIE

1988

1976

1998

1093-7404

England

1998

$1678-9199$

England

SCIE

2003

0141-1136

1738-642X

0267-8357

0027-5107

England

$\mathrm{SCl}$

South Korea SCIE

USA

Netherland

$\mathrm{SCl}$

1978

2010

2005

1964

$1383-5718$

Netherland

$\mathrm{SCl}$

1997

Netherland

$\mathrm{SCl}$

1964

1383-5742

6

English

1.548

English

3.584

English

5.756

English

1.604

12

English

1.617

English $\quad 1.057$

English $\quad 2.304$

English $\quad 2.012$

English $\quad 1.530$

English $\quad 1.077$

English $\quad 2.322$

English $\quad 2.727$

English 2.303

English $\quad 1.246$

English $\quad 3.667$

English

$6 \quad$ English

6

English

0.083

\section{4}

6

English

English

2.02

4

\section{4}

4

12

English

English

English

0.848

6

6

English

4

12
4
4
12
24

$12 \quad$ English $\quad 5.261$




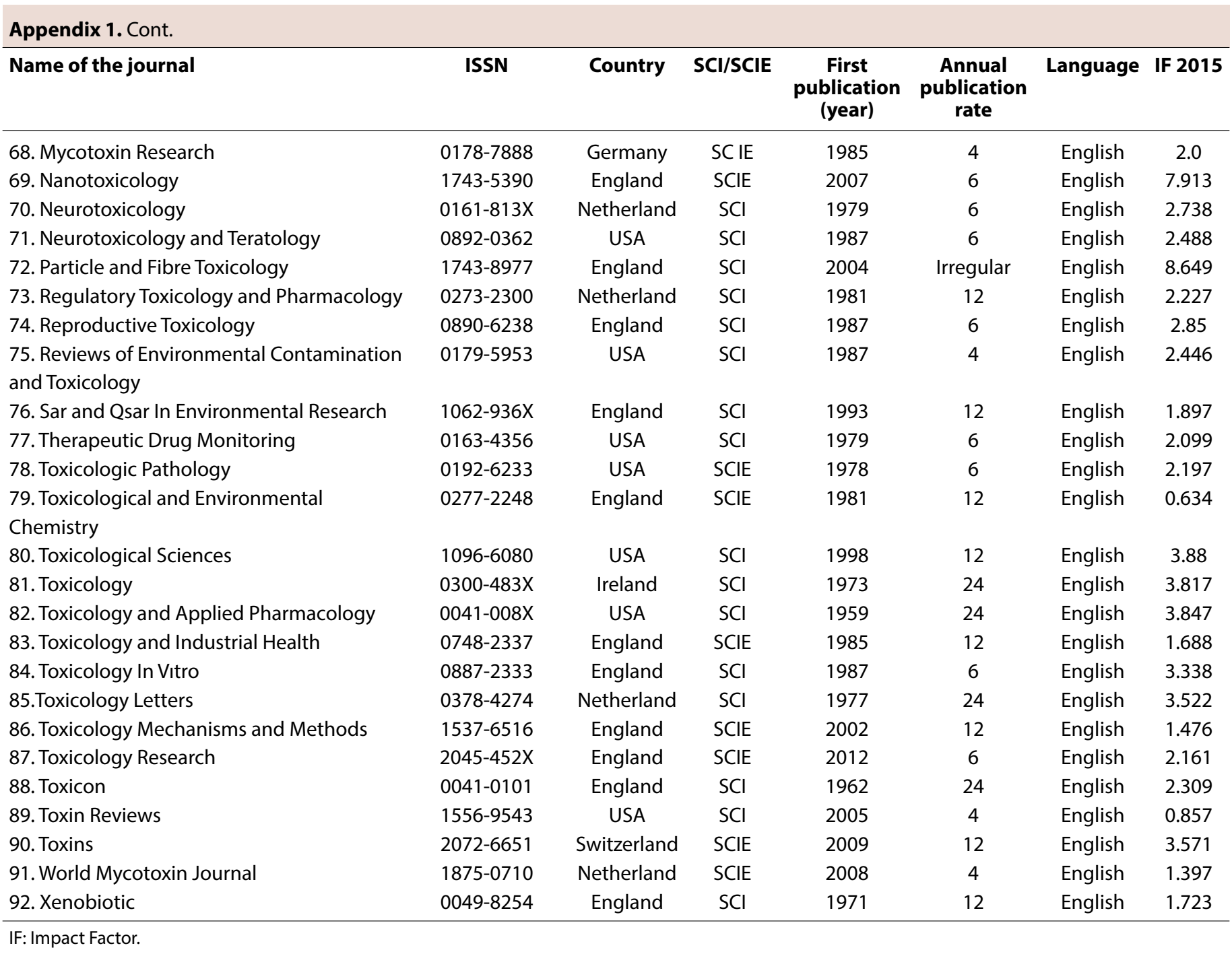


Appendix 2. Publications from Turkey in journals indexed in toxicology $\mathrm{SCl} / \mathrm{SCl}-\mathrm{E}$

Name of the Journal

\section{Total number of publications indexed in Web of Science (WoS)/ Pubmed (PM)}

Number of
Turkey-based
publications
indexed in Web
of Science (WoS)/
Pubmed (PM)

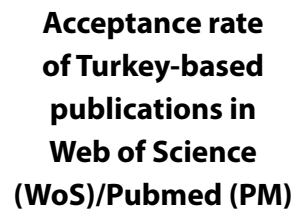

Acceptance rate of Turkey-based publications in Web of Science (WoS)/Pubmed (PM)

Average annual publication rate of Turkey-based articles

1. Alcohol
2. Annals of Occupational Hygiene
3. Annual Review of Pharmacology and Toxico
4. Aquatic Toxicology
5. Archives of Environmental Contamination
and Toxicology
6. Archives of Toxicology

7. Arhiv Za Higijenu Rada I Toksikologiju-Archives of Industrial Hygiene and Toxicology

8. Basic \& Clinical Pharmacology \& Toxicology

9. Biomarkers

10. Birth Defects Research Part A-Clinical and Molecular Teratology

11. Birth Defects Research Part B-Developmental and Reproductive Toxicology

12. BMC Pharmacology \& Toxicology

13. Bulletin of Environmental Contamination and Toxicology

14. Cardiovascular Toxicology

15. Cell Biology and Toxicology

16. Chemical Research In Toxicology

17. Chemical Speciation and Bioavailability

18. Chemico-Biological Interactions

19. Clinical Toxicology

20. Comparative Biochemistry and Physiology

C-Toxicology \& Pharmacology

21. Critical Reviews In Toxicology

22. Cutaneous and Ocular Toxicology

23. DNA Repair

24. Drug and Chemical Toxicology

25. Drug Safety

\begin{tabular}{|c|c|c|c|}
\hline 3250 (WoS) & 7 & 0.00006 & 0.212 \\
\hline 2713 (PM) & 7 & 0.258 & 0.212 \\
\hline 2837(WoS) & 0 & 0 & 0 \\
\hline 3088 (PM) & 0 & 0 & 0 \\
\hline 918 (WoS) & 1 & 0.108 & 0.035 \\
\hline 1044 (PM) & 0 & 0 & 0 \\
\hline 4581 (WoS) & 11 & 0.240 & 0.305 \\
\hline 3504 (PM) & 11 & 0.313 & 0.305 \\
\hline 4805 (WoS) & 33 & 0.686 & 0.750 \\
\hline 4487 (PM) & 33 & 0.735 & 0.750 \\
\hline 4869 (WoS) & 45 & 0.924 & 1.046 \\
\hline 4967 (PM) & 45 & 0.905 & 1.046 \\
\hline 489 (WoS) & 30 & 6.134 & 0.491 \\
\hline 2010 (PM) & 14 & 0.696 & 0.229 \\
\hline 7034 (WoS) & 86 & 1.222 & 6.61 \\
\hline 1970 (PM) & 65 & 3.299 & 5 \\
\hline 1324 (WoS) & 21 & 1.586 & 1.000 \\
\hline 1405 (PM) & 17 & 1.209 & 0.809 \\
\hline 3622 (WoS) & 10 & 0.276 & 0.714 \\
\hline 1433 (PM) & 2 & 0.139 & 0.142 \\
\hline 561 (WoS) & 1 & 0.178 & 0.071 \\
\hline 548 (PM) & 1 & 0.182 & 0.071 \\
\hline 119 (WoS) & 0 & 0 & 0 \\
\hline 285 (PM) & 0 & 0 & 0 \\
\hline 10327 (WoS) & 269 & 2.604 & 5.274 \\
\hline 12595 (PM) & 269 & 2.135 & 5.274 \\
\hline 439 (WoS) & 17 & 3.872 & 1.06 \\
\hline 602 (PM) & 19 & 3.156 & 1.18 \\
\hline 1282 (WoS) & 23 & 1.794 & 0.696 \\
\hline 1189 (PM) & 23 & 1.934 & 0.696 \\
\hline 6386 (WoS) & 2 & 0.031 & 0.689 \\
\hline 5304 (PM) & 2 & 0.377 & 0.689 \\
\hline 493 (WoS) & 11 & 2.231 & 0.305 \\
\hline 5984 (WoS) & 31 & 0.518 & 0.645 \\
\hline 6830 (PM) & 27 & 0.395 & 0.562 \\
\hline 7190 (WoS) & 49 & 0.681 & 4.08 \\
\hline 1776 (PM) & 44 & 2.477 & 3.66 \\
\hline 2182 (WoS) & 19 & 0.870 & 1.117 \\
\hline 2053 (PM) & 16 & 0.779 & 0.941 \\
\hline 752 (WoS) & 0 & 0 & 0 \\
\hline 853 (PM) & 0 & 0 & 0 \\
\hline 615 (WoS) & 230 & 37.398 & 19.16 \\
\hline 680 (PM) & 230 & 33.823 & 19.16 \\
\hline 2258 (WoS) & 4 & 2.170 & 0.266 \\
\hline 2216 & 4 & 2.211 & 0.266 \\
\hline 1404 (WoS) & 100 & 7.122 & 2.500 \\
\hline 1499 (PM) & 100 & 6.671 & 2.500 \\
\hline 4946 (WoS) & 42 & 0.848 & 1.55 \\
\hline 2387 (PM) & 2 & 0.083 & 0.074 \\
\hline
\end{tabular}


Appendix 2. Cont.

Name of the Journal

\section{Total number of publications indexed in Web of Science (WoS)/ Pubmed (PM)}

\begin{tabular}{|c|c|}
\hline $\begin{array}{l}\text { Number of } \\
\text { Turkey-based } \\
\text { publications }\end{array}$ & $\begin{array}{l}\text { Acceptance rate } \\
\text { of Turkey-based } \\
\text { publications in }\end{array}$ \\
\hline $\begin{array}{l}\text { indexed in Web } \\
\text { f Science (WoS)/ } \\
\text { Pubmed (PM) }\end{array}$ & $\begin{array}{c}\text { Web of Science } \\
\text { (WoS)/Pubmed (PM) }\end{array}$ \\
\hline
\end{tabular}

0.086

0.088

0.686

0.809

1.183

1.132

0.350

0.736

0.856

0.089

3.676

3.731

0.105

0.201

4.03

3.76

0.367

3.403

2.69

9.28

8.68

2.08

1.743

0.804

2.18

2.17

0.322

310 (WoS)

24 (PM)

2007 (WoS)

3227 (PM)

1753 (WoS)

1770 (PM)

1758 (WoS)

1980 (PM)

169 (WoS)

677 (PM)

2201 (WoS)

1799 (PM)

681 (WoS)

1026 (PM)

2142 (WoS)

1031 (PM)

3756 (WoS)

3690 (PM)

2900 (WoS)

3085 (PM)

\section{Average annual publication rate of Turkey-based articles}

0.206

0.206

0.714

0.809

1.75

1.75

0.600

0.600

0.266

0.266

3.333

3.333

0.28

0.342

5

4.80

2.8

2.6

0.775

3.88

3.88

3.77

3.555

0.24

5.65

5.51

0.09

0

10.07

11

0.8

0.8

0.333

0.31

0.11

0.19

1.03

1

0

0

0.9

0.9

0.05

0.025

1.15

49. Journal of Applied Toxicology 
Appendix 2. Cont.

Name of the Journal

\section{Total number of publications indexed in Web of Science (WoS)/ Pubmed (PM)}

Number of
Turkey-based
publications
indexed in Web
of Science (WoS)/
Pubmed (PM)

\section{Acceptance rate of Turkey-based publications in Web of Science (WoS)/Pubmed (PM)}
Average annual publication rate of Turkey-based articles

\begin{tabular}{|c|c|c|c|c|}
\hline \multirow{2}{*}{ 50. Journal of Biochemical and Molecular Toxicology } & 1002 (WoS) & 42 & 4.19 & 2.210 \\
\hline & 1037 (PM) & 46 & 4.435 & 2.421 \\
\hline \multirow{2}{*}{$\begin{array}{l}\text { 51. Journal of Environmental Pathology Toxicology } \\
\text { and Oncology }\end{array}$} & 602 (WoS) & 15 & 2.49 & 0.46 \\
\hline & 1180 (PM) & 39 & 3.305 & 1.21 \\
\hline \multirow{2}{*}{$\begin{array}{l}\text { 52. Journal of Environmental Science and Health } \\
\text { Part C-Environmental Carcinogenesis \& Ecotoxicology }\end{array}$} & 277 (WoS) & 0 & 0 & 0 \\
\hline & $164(\mathrm{PM})$ & 0 & & \\
\hline \multicolumn{5}{|l|}{ Reviews } \\
\hline \multirow{2}{*}{$\begin{array}{l}\text { 53. Journal of Exposure Science and Environmental } \\
\text { Epidemiology }\end{array}$} & 886 (WoS) & 1 & 0.112 & 0.090 \\
\hline & 925 (PM) & 2 & 0.216 & 0.18 \\
\hline \multirow{2}{*}{$\begin{array}{l}\text { 54. Journal of Food Safety and Food Quality-Archiv } \\
\text { Fur Lebensmittelhygiene }\end{array}$} & 1328 (WoS) & 94 & 7.07 & 1.51 \\
\hline & lot scanned (PM) & 0 & 0 & 0 \\
\hline \multirow[t]{2}{*}{ 55. Journal of Immunotoxicology } & $500($ WoS $)$ & 5 & 1 & 0.38 \\
\hline & 575 (PM) & 5 & 0.86 & 0.38 \\
\hline \multirow{2}{*}{$\begin{array}{l}\text { 56. Journal of Pharmacological and Toxicological } \\
\text { Methods }\end{array}$} & 2026 (WoS) & 5 & 0.246 & 0.2 \\
\hline & 1585 (PM) & 4 & 0.252 & 0.16 \\
\hline \multirow[t]{2}{*}{ 57. Journal of Toxicologic Pathology } & 357 (WoS) & 0 & 0 & 0 \\
\hline & 348 (PM) & 0 & & \\
\hline \multirow[t]{2}{*}{ 58. Journal of Toxicological Sciences } & 932 (WoS) & 5 & 0.536 & 0.12 \\
\hline & 2432 (PM) & 7 & 0.287 & 0.17 \\
\hline \multirow{2}{*}{$\begin{array}{l}\text { 59. Journal of Toxicology and Environmental } \\
\text { Health-Part A-Current Issues }\end{array}$} & 2431 (WoS) & 25 & 1.028 & 1.31 \\
\hline & 2663 (PM) & 34 & 1.27 & 1.78 \\
\hline \multirow{2}{*}{$\begin{array}{l}\text { 60. Journal of Toxicology and Environmental } \\
\text { Health-Part B-Critical Reviews }\end{array}$} & 334 (WoS) & 0 & 0 & 0 \\
\hline & 325 (PM) & 0 & & \\
\hline \multirow{2}{*}{$\begin{array}{l}\text { 61. Journal of Venomous Animals and Toxins } \\
\text { Including Tropical Diseases }\end{array}$} & 656 (WoS) & 21 & 3.20 & 1.5 \\
\hline & 198 (PM) & 0 & 0 & 0 \\
\hline \multirow[t]{2}{*}{ 62. Marine Environmental Research } & 3764 (WoS) & 16 & 0.425 & 0.410 \\
\hline & 1858 (PM) & 9 & 0.484 & 0.230 \\
\hline \multirow[t]{2}{*}{ 63. Molecular \& Cellular Toxicology } & 1043 (WoS) & 0 & 0 & 0 \\
\hline & lot scanned (PM) & 0 & & \\
\hline \multirow[t]{2}{*}{ 64. Mutagenesis } & 3718 (WoS) & 15 & 0.403 & 1.25 \\
\hline & 2449 (PM) & 13 & 0.53 & 1.08 \\
\hline \multirow{2}{*}{$\begin{array}{l}\text { 65. Mutation Research-Fundamental and Molecular } \\
\text { Mechanisms of Mutagenesis }\end{array}$} & 4071 (WoS) & 19 & 0.466 & 0.354 \\
\hline & & 112 & 0.564 & 2.24 \\
\hline \multirow{2}{*}{$\begin{array}{l}\text { 66. Mutation Research-Genetic Toxicology and } \\
\text { Environmental Mutagenesis }\end{array}$} & 3445 (WoS) & 83 & 2.409 & 1.56 \\
\hline & & 112 & 0.564 & 2.24 \\
\hline \multirow[t]{2}{*}{ 67. Mutation Research-Reviews In Mutation Research } & 677 (WoS) & 0 & 0 & 0 \\
\hline & & 112 & 0.564 & 2.24 \\
\hline \multirow[t]{2}{*}{ 68. Mycotoxin Research } & 120 (WoS) & 1 & 0.833 & 0.03 \\
\hline & 1008 (PM) & 6 & 0.595 & 0.18 \\
\hline \multirow[t]{2}{*}{ 69. Nanotoxicology } & 730 (WoS) & 1 & 0.136 & 0.10 \\
\hline & $662(\mathrm{PM})$ & 1 & 0.151 & 0.10 \\
\hline \multirow[t]{2}{*}{ 70. Neurotoxicology } & 4380 (WoS) & 14 & 0.319 & 0.36 \\
\hline & 3538 (PM) & 12 & 0.339 & 0.31 \\
\hline 71. Neurotoxicology and Teratology & 2982 (WoS) & 12 & 0.402 & 0.40 \\
\hline & 2177 (PM) & 12 & 0.597 & 0.43 \\
\hline 72. Particle and Fibre Toxicology & 433 (WoS) & 0 & 0 & 0 \\
\hline & 473 (PM) & 0 & & \\
\hline 73. Regulatory Toxicology and Pharmacology & 3326 (WoS) & 10 & 0.300 & 0.27 \\
\hline & 3419 (PM) & 12 & 0.350 & 0.33 \\
\hline
\end{tabular}




\section{Appendix 2. Cont.}

\section{Name of the Journal}

\section{Total number of publications indexed in Web of Science (WoS)/ Pubmed (PM)}

Number of
Turkey-based
publications
indexed in Web
of Science (WoS)/
Pubmed (PM)

Acceptance rate of Turkey-based publications in Web of Science (WoS)/Pubmed (PM)
Average annual publication rate of Turkey-based articles

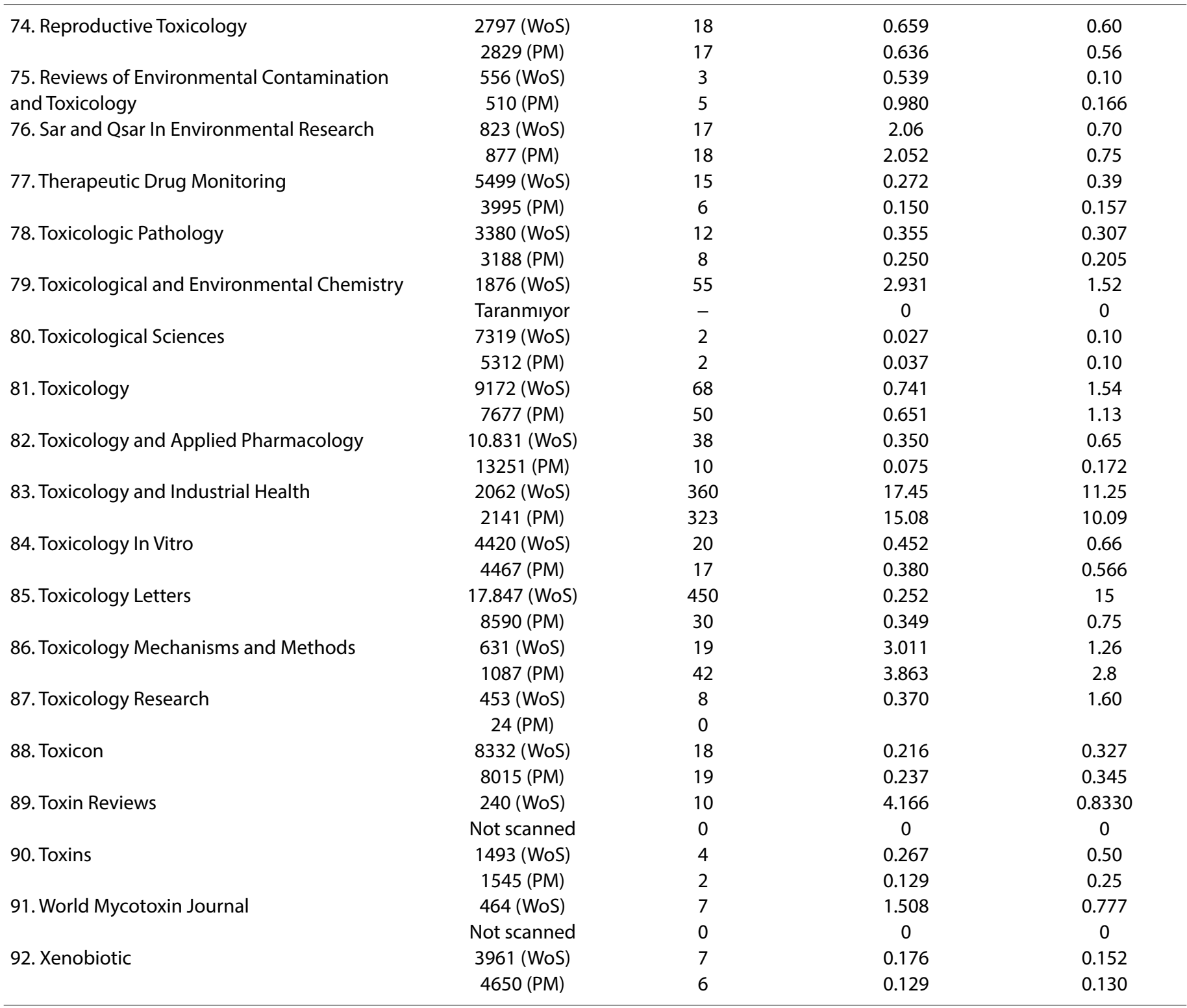

